\title{
Emerging trends in molecular systematics and molecular phylogeny of mayflies (Insecta: Ephemeroptera)
}

\author{
K.G. Sivaramakrishnan ${ }^{1}$, K.A. Subramanian ${ }^{2}$, M. Arunachalam ${ }^{3}$, C. Selva Kumar ${ }^{4}$ \\ \& S. Sundar ${ }^{5}$ \\ ${ }^{1}$ Flat No.3, Rams Apartments, No.7 Natesan Street, T. Nagar, Chennai, Tamil Nadu 600017, India \\ ${ }^{2}$ Zoological Survey of India, Western Regional Station, P.C.N.T. Post, Rawet Road, Akurdi, Pune, Maharastra 411044, India \\ ${ }^{3,4,5}$ Sri Paramakalyani Centre for Environmental Sciences, Manonmaniam Sundaranar University, Alwarkurichi, Tamil Nadu 627412, India \\ Email: ${ }^{1}$ kgskrishnan@gmail.com, ${ }^{2}$ subbuka.zsi@gmail.com (corresponding author), ${ }^{3}$ arunacm@gmail.com, \\ ${ }^{4}$ selvaaa06@gmail.com, ${ }^{5}$ sundarstreco@gmail.com
}

Date of publication (online): 26 August 2011 Date of publication (print): 26 August 2011 ISSN 0974-7907 (online) | 0974-7893 (print)

\section{Editor: V.V. Ramamurthy}

\section{Manuscript details:}

Ms \# 02661

Received 29 December 2010

Final received 21 July 2011

Finally accepted 29 July 2011

Citation: Sivaramakrishnan, K.G., K.A Subramanian, M. Arunachalam, C.S. Kumar \& S. Sundar (2011). Emerging trends in molecular systematics and molecular phylogeny of mayflies (Insecta: Ephemeroptera). Journal of Threatened Taxa 3(8): 1975-1980.

Copyright: (C) K.G. Sivaramakrishnan, K.A Subramanian, M. Arunachalam, C. Selva Kumar \& S. Sundar 2011. Creative Commons Attribution 3.0 Unported License. JoTT allows unrestricted use of this article in any medium for non-profit purposes, reproduction and distribution by providing adequate credit to the authors and the source of publication.

Author Detail: see end of this article.

Author Contribution: KGS and KAS conceived and prepared the review. MA actively participated in the discussion of preparation of the manuscript and provided critical inputs. CSK and SS helped in compiling the literature.

Acknowledgements: K.G.Sivaramakrishnan is grateful to Dr. M. Arunachalam for having invited him to Sri Paramakalyani Centre for Environmental Sciences, Manonmaniam Sundaranar University, Alwarkurichi, Tamilnadu, India. He is indebted to authorities of Manonmaniam Sundaranar University for having offered facilities to carry out a UGC Major Project, during which period he could interact with co-authors to organize this review. K.A.Subramanian is grateful to the Director, Zoological Survey of India for providing facilities to prepare the manuscript.

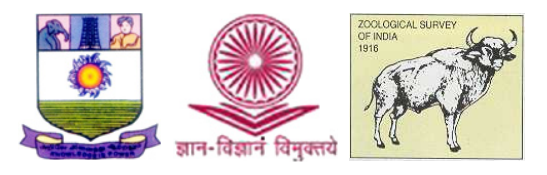

(c) (7) (口)

OPEN ACCESS | FREE DOWNLOAD
Abstract: Current trends are reviewed in the molecular systematics and phylogeny of the Ephemeroptera (mayflies), an ancient monophyletic lineage of pterygote insects. Theories of mayfly origins are analyzed, followed by a discussion of higher classification schemes in light of recent developments in molecular systematics. Ephemeroptera evolution is a classic example of ancient rapid radiation, presenting challenges for phylogenetic analysis. The utility of combined studies of morphological and molecular data is substantiated with examples and the role of molecular systematics in unraveling the taxonomy of cryptic species complexes is highlighted. The importance of DNA barcoding in mayfly taxonomy is discussed in the light of recent progress, and future contributions of genetics to the study of taxonomy, ecology and evolution in mayflies are discussed.

Keywords: Cryptic species, DNA barcoding, Ephemeroptera, molecular phylogeny, molecular systematics.

\section{INTRODUCTION}

The order Ephemeroptera presently encompasses over 3000 species and 400 genera, constituting at least 42 described families (Barber-James et al. 2008). The Ephemeroptera (mayflies) are an archaic lineage of insects, dating back to the late Carboniferous or early Permian periods, some 290 mya (Brittain \& Sartori 2003). They occupy freshwater and brackish water habitats across the world, with the exception of Antarctica. The nymphs are immature stages inhabiting lentic and lotic waters. The imagos or adults are terrestrial; they lack mouth parts and do not feed, relying on nutritional build up during immature stages. They have an ephemeral lifespan of a day or two and their only function is reproduction. The presence of a subimago with functional wings at the penultimate moult is unique to pterygote insects. The winged stages of Ephemeroptera, as with Odonata (dragonflies and damselflies) and the extinct Palaeodictyoptera, cannot fold their wings horizontally over the abdomen as neopterans can.

This article briefly reviews current trends in the molecular systematics and phylogeny of the Ephemeroptera and discusses how combined analysis of morphological and molecular data can be used to fine tune phylogenetic conclusions.

\section{MAYFLY ORIGINS}

The phylogenetic position of Ephemeroptera within the winged insects 
(Pterygota) is hotly debated by systematists, and significant disagreement still exists in morphological and molecular studies. The first complete mitochondrial genome of a heptageniid mayfly, Parafronurus youi was sequenced using a long PCR-based approach by Zhang et al. (2008). In their analysis, the basal Ephemeroptera hypothesis (Ephemeroptera versus (Odonata + Neoptera)) was supported. This result also received strong support by the nucleotide and amino acid datasets from mitochondrial protein-coding genes with BI and ML analyses. Zhang et al. (2008) tentatively concluded that mitochondrial genomes can answer the difficult question of the basic relationships among the winged insects. Ephemeroptera evolution is a classic example of "ancient rapid radiation of insects" presenting challenges for phylogenetic analysis because such radiations take place over short periods of time and allow few distinctive phylogenetic markers to accumulate among lineages.

The Ephemeroptera, Odonata and Neoptera present a challenging phylogenetic tree shape, regardless of their true relationships, because the first pterygotes may have emerged up to 400 mya, but the earliest representatives of their extant descendants is much younger than the first emergence of the lineage whose relationships are in question (Whitfield \& Kjer 2008).

\section{MOLECULAR SYSTEMATICS AND HIGHER CLASSIFICATION}

The original subordinal classification of McCafferty \& Edmunds (1979), based mostly on thoracic morphology and wing pad position, comprised the holophyletic suborder Pannota and the paraphyletic suborder Schistonota indicating the retention of certain plesiomorphic (ancestral) traits. It was realized that monophyly derived from synapomorphy (shared derived characters) should be the driving force behind any taxonomic classification(Hennig 1966, 1979; Farris 1979). Later, McCafferty (1991) proposed 3 different suborders (Pisciforma, Setisura and Rectracheata) and traced phylogenetic relationships within and among the suborders. Concurrent to McCafferty's work, Kluge $(1988,1998)$ independently proposed two suborders for Ephemeroptera. His suborder Furcatergalia is equivalent to McCafferty's Rectracheata, except the exclusion of Oniscigastridae form Furcatergalia. The other suborder proposal (Kluge 1988) was
Costatergalia, which is equal to McCafferty's (1991) Pisciforma + Setisura + Oniscigastridae. Topological comparison of Kluge's system and McCafferty' system of mayfly classification is presented in Fig. 1, after Ogden et al. (2009). In contrast to previous hypotheses based on morphological observations, the relationships inferred from the molecular data (Ogden \& Whiting 2005 ) were congruent in some cases, but incongruent in others. In their analysis, the groups, Furcatergalia, Pannota, Carapacea, Ephemerelloidea and Caenoidea and 15 families were supported as monophyletic. On the other hand, Setisura, Pisciforma, Baetoidea, Siphlonuroidea, Ephemeroidea, Heptagenoidea and five families (having more than one taxon represented) were not supported as monophyletic.

However, evidence supports the notion that combined data (morphology + molecular data) analysis provides a more robust estimate of phylogenetic relationships. The study of Ogden et al. (2009) represents the first formal morphological and combined (morphological and molecular) phylogenetic analyses of the order Ephemeroptera. Taxonomic sampling comprised 112 species in 107 genera, including 42 recognized families (all major lineages of Ephemeroptera). Morphological data consisted of 101 morphological characters. Molecular data were acquired from DNA sequences of $12 \mathrm{~S}, 16 \mathrm{~S}$, $18 \mathrm{~S}, 28 \mathrm{~S}$ and H3 genes. The Asian genus Siphluriscus (Siphluriscidae) was supported as sister to all other mayflies. The lineages Carapacea, Furcatergalia, Fossoriae, Pannota, Caenoidea and Ephemerelloidea were supported as monophyletic. However, some recognized families (for example, Ameletopsidae and Coloburiscidae) and major lineages (such as Setisura, Pisciforma and Ephemeroidea among others) were not supported as monophyletic, mainly due to convergences within nymphal characters (Ogden et al. 2009).

\section{EFFICACYOFCOMBINED MORPHOLOGICAL AND MOLECULAR PHYLOGENY AND SYSTEMATICS - EXAMPLES FROM THE EPHEMEROPTERA}

It is quite obvious that most previous reconstructions of phylogeny and classification were strongly hampered by superficial external morphological similarities, which do not always reflect the true phylogeny of the 

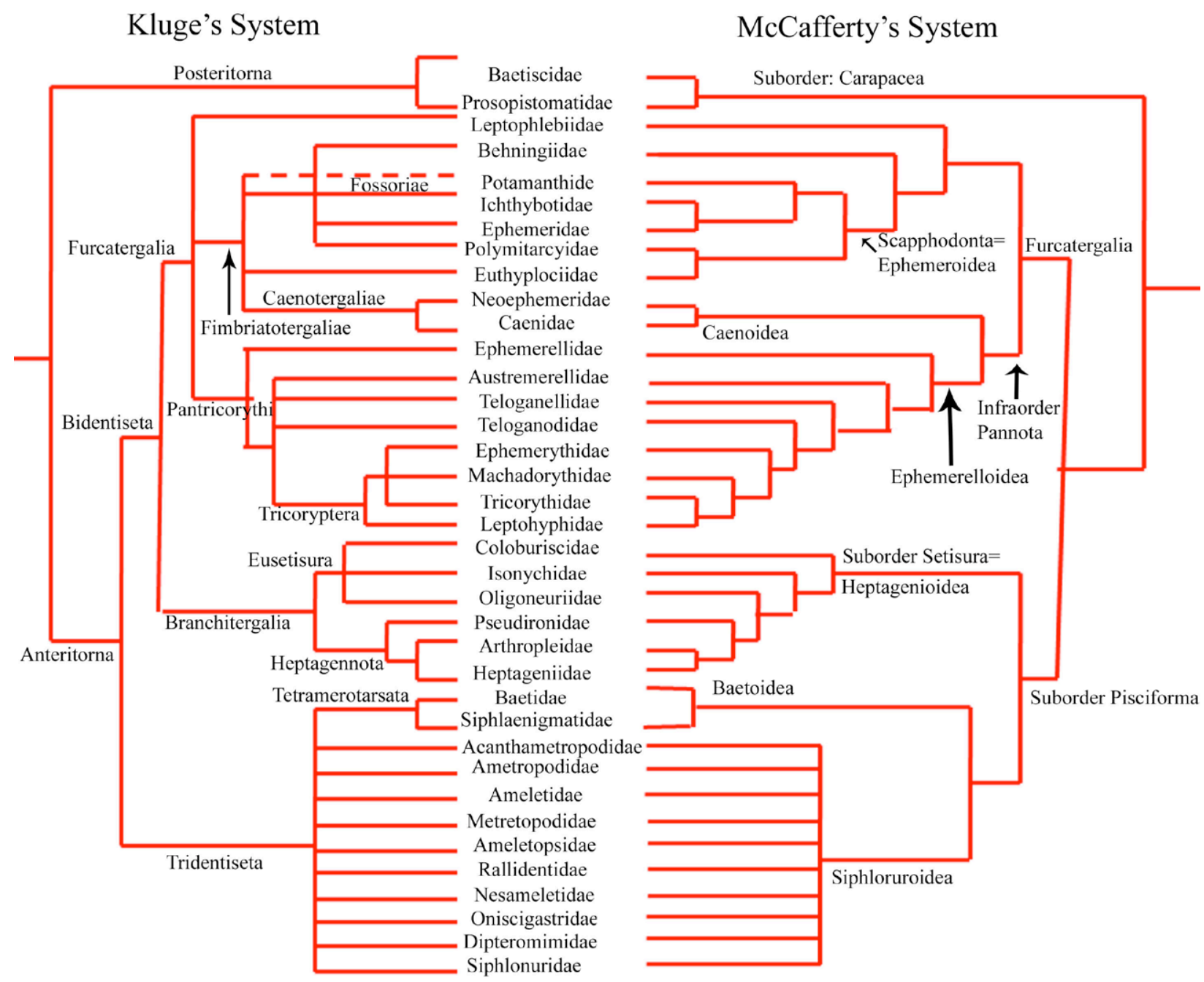

Figure 1. Topological comparison of Kluge's system and McCafferty's system of mayfly classification (after Ogden et al. 2009).

Order. Homoplasies therefore seem a dominant trait in mayfly morphology and behaviour, especially in nymphs (Ogden et al. 2009) and combined analysis may solve many riddles. Apart from the outstanding recent contribution of Ogden et al. (2009) on these lines towards evolving a new paradigm in mayfly phylogeny, some families notably, Leptophlebiidae (O’Donnell \& Jockusch 2008), Baetidae (Gattolliat et al. 2008) and Ephemerellidae (Ogden et al. 2009) have received considerable attention regarding intrafamilial relationships, in which molecular phylogenetic tools were extensively employed.

Using two nuclear genes (the D2 $+\mathrm{D} 3$ region of 28S ribosomal DNA and histone H3) and maximum parsimony (MP), maximum likehood (ML) and Bayesian inference (BI), O'Donnell and Jockusch (2008) inferred the evolutionary relationships of
69 leptophlebiids sampled from six continents and representing 30 genera plus 11 taxa of uncertain taxonomic rank from Madagascar and Papua New Guinea. Although they did not recover monophyly of the Leptophlebiidae, monophyly of two of the three leptophlebiid subfamilies, Habrophlebiinae and Leptophlebiinae, was recovered with moderate to strong support in most analyses. The Atalophlebiinae was rendered paraphyletic as a result of the inclusion of numbers of Ephemerellidae or the Leptophlebiinae clade. For the species-rich Atalophlebiinae, four groups of taxa were recovered with moderate to strong branch support: (i) an endemic Malagasy clade, (ii) a Paleoaustral group, a pan-continental cluster with members drawn from across the Southern Hemisphere, (iii) the Choroterpes group uniting fauna from North America, southeast Asia and Madagascar and (iv) a 
group uniting three new world genera, Thraulodes, Farrodes and Traverella.

Gattolliat et al. (2008) reconstructed the first comprehensive molecular phylogeny of the Afrotropical Baetidae. They sequenced a total of ca. $2300 \mathrm{bp}$ from nuclear (18S) and mitochondrial (12S and $16 \mathrm{~S}$ ) gene regions from 65 species belonging to 26 genera. They used three different approaches of phylogeny reconstruction viz., direct optimization, maximum parsimony and maximum likelihood. The molecular reconstruction indicated the Afrotropical Baetidae require a global revision at a generic as well as suprageneric level.

The investigation of Ogden et al. (2009) represented the combined molecular and morphological analysis for the mayfly family Ephemerellidae (Ephemeroptera), with a focus on the relationships of genera and species groups of the subfamily Ephemerellinae. The phylogeny was constructed based on DNA sequence data from three nuclear (18S rDNA, 28S rDNA, histone H3) and two mitochondrial (12S rDNA, 16S rDNA) genes, and 23 morphological characters. Ephemerella, the largest genus of Ephemerellidae, and Serratella were not supported as monophyletic lineages. Strongly supported as monophyletic include a grouping of the Timpanoginae genera Timpanoga, Dannella, Dentatella and Eurylophella, and groupings of the Ephemerellinae genera Torleya, Hyrtanella and Crinitella and the genera Kangella, Uracanthella and Teloganopsis. Further study and analysis of Ephemerellidae morphology is needed, and classification should be revised, if it is to reflect true phylogenetic relationships (Ogden et al. 2009).

\section{MOLECULAR SYSTEMATICS AND CRYPTIC SPECIES COMPLEX}

Genetic studies have highlighted cryptic diversity in many well-known taxa including aquatic insects, with the general implication that there are more species than are currently recognized. Baetis rhodani Pictet are among the most widespread, abundant and ecologically important of all European mayflies (Ephemeroptera), and used widely as biological indicators of stream quality. Traditional taxonomy and systematics have never fully resolved differences among suspected cryptic species in the B. rhodani complex because morphological characters alone do not allow reliable distinction. This is particularly true among larvae, the life-stage used most widely in biomonitoring studies. Williams et al. (2006) assessed the molecular diversity of this complex in one of the largest such studies of cryptic species in the order Ephemeroptera to date. Phylogenies were constructed using data from the mitochondrial cytochrome oxidase submit I (COI) gene. Two monophyletic groups were recovered consisting of one major haplogroup and a second clade of six smaller but distinct haplogroups. Haplogroup divergence ranged from $0.2-3 \%$ (within) to $8-19 \%$ (among) with the latter values surpassing maxima typically reported for other insects, and provided strong evidence for cryptic species in the B. rhodani complex. However, the taxonomic status of these seven haplogroups remains to be defined clearly.

The potential implications of cryptic species in the B. rhodani complex on current and future ecological studies are particularly far-reaching given the large number of studies carried out on what now appears to be several possible distinct taxa. These results have wider relevance since cryptic species have been detected in other aquatic insects (Jackson \& Resh 1998), and the presence and diversity of several taxa are widely used as biological indicators (Mason 1996). The presence of cryptic species also has ramifications for the assessment of biodiversity in general, and the ability to account for them in future studies emphasizes the need to correlate genetic differences from multilocus data, with identifiable morphological characters and/or other factors including physiology.

\section{DNA BARCODING AND MAYFLY TAXONOMY}

The tool of DNA barcoding shows great potential for use by those studying the systematics of many Ephemeroptera species groups. One example of the utility of barcoding is the verification of stage associations, especially those not made by careful rearing. Recent revisionary study, on the family Ephemerellidae Klapalek provides an illustration. The species concept of Ephemerella altana Allen, a western Nearctic taxon, had been based on a larva belonging to the genus Ephemerella Walsh and an adult of Serretella Edmunds. Had barcoding technology been available at the time of E. altana's discovery and description, it potentially could have shown that this association was 
erroneous. Furthermore, barcoding could have helped to resolve the species identities of the larva and adult. Based on traditional specimen comparisons, the larva is thought to be that of the transcontinental species, Ephemerella excrucians Walsh, and the adult to be that of the western species, Serretella micheneri (Traver). Ephemerella excrucians exhibits an amazing amount of morphological variability throughout its wide geographic range, which begs the question of whether the current species concept might contain various cryptic lineages that are unrecognizable by traditional, morphological means. Barcoding technology could be used to study various populations, including those from type localities, and could provide a guideline for decisions about species identities and boundaries (Zhou et al. 2008). Zhou et al. (2009) have made a pioneering attempt to generate a DNA barcode reference library for three insect orders- Ephemeroptera, Plecoptera and Trichoptera at one site in the Canadian subarctic. This study has demonstrated that DNA barcoding holds great promise as a tool for rapid biodiversity assessment in unknown faunas. A very close correspondence was observed between morphospecies as determined by taxonomic experts and barcode clusters designated using a standard sequence threshold. Several cases of proposed splitting may reflect cryptic species.

DNA barcodes of stream mayflies will improve descriptions of community structure and water quality for both ecological and bioassessment purposes (Sweeney et al. 2011). Rapid assessment of biodiversity will aid the selection of sites of special conservation value and will help to focus the efforts of taxonomists in revising and characterizing the diversity of life (Zhou et al. 2009).

\section{CONCLUSIONS}

Future perspectives on systematics and phylogeny of Ephemeroptera using recent molecular tools are highlighted below:

- Four sequencing markers which are well-surveyed and informative across a range of divergences viz., the mitochondrial COI and $16 \mathrm{~S}$ genes, and the nuclear $18 \mathrm{~S}$ and EF-I $\alpha$ genes are suggested as standards for comparison for insect molecular systematic studies (Caterino et al. 2000).

- Species delineation continues to be one of the primary applications of genetic techniques. Application of the Generalized Mixed Yule-coalescent (GMYC) model to species circumscription using single-locus DNA appears rewarding (Pons et al. 2006; Fontaneto et al. 2007). This approach has been applied successfully to 64 species of mayflies in Madagascar (Monaghan et al. 2009).

- Investigators of the demographic history of closely related populations or species can use several nuclear DNA sequences to test specific hypotheses of how past geological events influence observed patterns (e.g. Knowles et al. 2007). These techniques allow one to test a priori hypotheses rather than post hoc conclusions from patterns (Monaghan \& Sartori 2009).

- Wilcock et al. (2005) demonstrated very well how the combination of ecological and genetic research, applied to several parts of the life cycle, can greatly advance our understanding of how populations function in nature.

- Routine sampling of population- and species- level genetic diversity, combined with coalescent-based methods of species delineation has great potential to become a standard procedure for the study of poorly known taxonomic groups like Ephemeroptera (Gattolliat \& Monaghan 2010).

\section{REFERENCES}

Barber-James, H.M., J.L. Gattolliat, M. Sartori \& M.D. Hubbard (2008). Global diversity of mayflies (Ephemeroptera: Insecta) in freshwater. Hydrobiologia 595: 339-350.

Brittain, J.E. \& M. Sartori (2003). Ephemeoptera of Insects. (Edited by Resh, V.H. \& R.T. Carde). Academic Press, San Diego, 373-380pp.

Caterino, M.S., S. Cho \& F.A.H. Sperling (2000). The current state of insect molecular systematics: a thriving tower of Babel. Annual Review of Entomology 45: 1-54.

Farris, J.S. (1979). On the naturalness of phylogenetic classification. Systematic Zoology 28: 200-214.

Fontaneto, D., E.A. Herniou, C. Boshetti, M. Caprioli, G. Melone, C. Ricci \& T.G. Barraclough (2007). Independently evolving species in asexual bdelloid rotifers. PLoS Biology 5: 914-921.

Gattolliat, J.L. \& M.T. Monagan (2010). DNA-based association of adults and larvae in Baetidae (Ephemeroptera) with the description of a new Adnoptilum in Madagascar. Journal of the North American Benthological Society 29(3): 1042-1057. (http://www.bioone.org/doi/abs/10.1899/09- 
119.1).

Gattolliat, J.L., M.T. Monaghan, M. Sartori, J.M. Elouard, H. Barber-James, P. Derleth, O. Glaizot, Ferdy de Moor \& A.P. Vogler (2008). A molecular analysis of Afrotropical Baetidae, pp. 219-232. In: Hauer F.R., J.A. Stanford \& R.L. Newell (eds.) International advances in the Ecology, Zoogeography and Systematics of mayflies, and stoneflies Vol. 128. University of California Publication in Entomology, 422pp.

Hennig, W. (1979). The position of systematic among the biological sciences, pp. 1-99. In: Phylogenetic Systematics. University of Illinois, Chicago, 350pp.

Hennig, W. (1966). Phylogenetics Systematics. University of Illinois Press, Urbana, 263pp.

Jacokson, J.K. \& V.H. Resh (1998). Morphologically cryptic species confound ecological studies of the caddisfly genus Gumaga (Trichoptera: Sericostomatidae) in Northern California. Aquatic Insects 20: 69-84.

Kluge, N.J. (1988). The problem of the homology of the tracheal gills and paranotal processi of mayfly larvae and wings of the insects with reference to the taxonomy and phylogeny of the order Ephemeroptera. Chteniya Pamyati N.A. Kholodkovskogo (Lectures in Memory of N.A. Kholodkovski), Leningrad Academy of Sciences, Leningrad (in Russian), pp. 48-77.

Kluge, N.J. (1998). Phylogeny and higher classification of Ephemeroptera. Zoosystematica Rossica 7: 255-269.

Knowles, L.L., B.C. Carstens \& M.L. Keat (2007). Coupling genetic and ecological-niche models to examine how past population distributions contribute to divergence. Current Biology 17: 940-946.

Mason, C.F. (1996). Biology of Freshwater Pollution. Longman Group Limited, England, 1-4pp.

McCafferty, W.P. \& G.F. Edmunds (1979). The higher classification of the Ephemeroptera and its evolutionary basis. Annals of the Entomological Society of America 72: 5-12.

McCafferty, W.P. (1991). Toward a phylogenetic classification of the Ephemeroptera (Insecta): a commentary on systematic. Annals of the Entomological Society of America 84: 343 360.

Monaghan, M.T. \& M. Sartori (2009). Genetic contributions to the study of taxonomy, ecology, and evolution of mayflies (Ephemeroptera): review and future perspectives. Aquatic Insects 31: 19-39.

Monaghan, M.T., R. Wild, M. Elliot, T. Fujisawa, M. Balke, D. J.G. Inward, D.C. Lees, R. Ranaivosolo, P. Eggleton, T.G. Barraclough \& A.P. Vogler (2009). Accelerated species discovery on Madagascar using a coalescent-based model of species delineation. Systematic Biology 58: 298-311.

O'Donnell, B. \& E.L. Jockusch (2008). Phylogenetic relationships of leptophlebiid mayflies as inferred by histone H3 and 28S ribosomal DNA, Systematic Entomology 33: $651-667$.

Ogden, T.H. \& M.F. Whiting (2005). Phylogeny of Ephemeroptera (mayflies) based on molecular evidence.
Molecular Phylogenetics and Evolution 37: 625-643.

Ogden, T.H., J. L. Gattolliat, M. Sartori, A.H. Staniczek, T. Soldan \& M.F. Whiting (2009). Towards a new paradigm in mayfly phylogeny (Ephemeroptera): Combined analysis of morphological and molecular data. Systematic Entomology 34: 616-634.

Pons, J., T.G. Barraclough, J.Gomez-Zurita, A. Cardoso, D.P. Duran, H.S. Azell, S. Kamoun, W.D. Sumlin \& A.P. Vogler (2006). Sequence-based species delimitation for the DNA taxonomy of undescribed insects. Systematic Biology 55: 595-609.

Sweeney, B.W., Battle, J.M., Jackson, J.K. \& T. Dapkey (2011). Can DNA barcodes of stream macroinvertebrates improve descriptions of community structure and water quality? Jounal of the North American Benthological Society 30(1): 195-216.

Whitfield, J.B. \& K.M. Kjer (2008). Ancient Rapid Radiations of Insects: Challenges for Phylogenetic Analysis. Annual Review Entomology 53: 449-472.

Wilcock, H.R., M.W. Bruford, A.G. Hildrew \& R.A. Nichols (2005). Recruitment, kin and the spatial genetic structure of a caddisfly in a southern English stream. Freshwater Biology 50: 1499-1514.

Williams, H.C., S.J. Ormerod \& M.W. Bruford (2006). Molecular systematics and phylogeography of the crptic species complex (Ephemeroptera, Baetidae). Molecular Phylogenetics and Evolution 40: 370-382.

Zhang, J., C. Zhou, Y. Gai, D. Song \& K. Zhou (2008). The complete mitochondrial genome of Parafronurus youi (Insecta: Ephemeroptera) and phylogenetic position of the Ephemeroptera. Gene 424: 18-24.

Zhou, X., L.M. Jacobus, \& P.D.N. Hebert (2008). DNA Barcoding North American mayflies - a call for international collaboration. The Mayfly Newsletter (Southwestern Oklahoma State University, USA) 15(2): 12.

Zhou, X., S.J. Adamowicz, L.M. Jacobus, R.E. Dewalt \& P.D.N. Hebert (2009). Towards a comprehensive barcode library for arctic life - Ephemeroptera, Plecoptera, and Trichoptera of Churchill, Manitoba, Canada. Frontiers in Zoology 6: 30 (doi: 10.1186/1742-9994-6-30).

Author Details: DR. K.G. SIVARAMAKRISHNAN has been working on aquatic insects especially on the systematics and biogeography of mayflies (Ephemeroptera) of India over last 35 years. He has many publications on the subject in international and national journals. Currently he is based in Chennai.

DR. K.A. Subramanian is a scientist at Zoological Survey of India, Kolkata and has been working on aquatic insects since 1998 .

Dr. M. ARunachalam Professor at Sri Paramakalayni Centre for Environmental Sciences, Manonmaniam Sundaranar University, Alwarkuruchi. He is a freshwater biologist and Ichthyologist and has been working on ecology and systematics of freshwater organisms, especially the freshwater fishes.

C. Selva KUmAR Doctoral student at Sri Paramakalayni Centre for Environmental Sciences, Manonmaniam Sundaranar University, Alwarkuruchi. Currently working on Ephemeroptera of KalakkadMundanthurai Tiger Reserve.

S. SUNDAR Doctoral student at Sri Paramakalayni Centre for Environmental Sciences, Manonmaniam Sundaranar University, Alwarkuruchi. Currently working on Naucoridae (Hemiptera) of southern Western Ghats. 